\title{
Hubungan Dukungan Keluarga dengan Kejadian Depresi pada Usia Tua di Nagari Tanjung Banai Aur, Kecamatan Sumpur Kudus, Kabupaten Sijunjung Tahun 2012
}

\author{
Figa Prima Dani, Yaslinda Yaunin, Edison
}

\begin{abstract}
Abstrak
Depresi pada usia tua merupakan keadaan yang ditandai dengan perasaan sedih, kurang bersemangat, merasa gelisah, penurunan konsentrasi, selalu berpikiran buruk, dan susah untuk sosialisasi dengan lingkungan sekitar serta mudah putus asa dalam menghadapi masalah. Dengan adanya dukungan keluarga berupa dukungan informasi, dukungan penilaian, dukungan instrumental, dan dukungan emosional akan menurunkan kejadian depresi pada usia tua. Penelitian ini bertujuan untuk mengetahui hubungan dukungan keluarga dengan kejadian depresi pada usia tua di Nagari Tanjung Banai Aur, Kecamatan Sumpur Kudus, Kabupaten Sijunjung. Jenis penelitian yang digunakan adalah observasional dengan pendekatan cross sectional. Sampel yang diambil dalam penelitian ini adalah usia tua yang berumur lebih dari 60 tahun yang tinggal bersama keluarganya di Nagari Tanjung Banai Aur, Kecamatan Sumpur Kudus, Kabupaten Sijunjung yaitu sebanyak 82 orang, dengan metode pengambilan sampelnya adalah stratified sampling. Usia tua yang mengalami depresi memiliki dukungan keluarga rendah. Terdapat hubungan yang signifikan antara dukungan keluarga dengan kejadian depresi pada usia tua di Nagari Tanjung Banai Aur, Kecamatan Sumpur Kudus, Kabupaten Sijunjung.
\end{abstract}

Kata kunci: usia tua, depresi pada usia tua, dukungan keluarga

\begin{abstract}
Depression in old age is a state characterized with feelings of sadness, less excited, feeling jittery, decreased concentration, always thinking bad, and hard to socialize with their surroundings and easy to despair in dealing with problems. With the support of the family such as informational support, appraisal support, instrumental support, and emotional support will reduce the incidence of depression in old age. This study is aimed to determine the relationship of family support with the incidence of depression in old age in Nagari Tanjung Aur Banai, Kecamatan Sumpur Kudus Kabupaten Sijunjung. The study's method is an observational with cross-sectional approach. Samples in this study were people with age more than 60 years who lives with his/her in Nagari Tanjung Aur Banai, Kecamatan Sumpur Kudus Kabupaten Sijunjung, which were counted as 82 people, and taken by stratified sampling method. old age with depression have low family support. There is a significant relationship between family support with the incidence of depression in old age in Nagari Tanjung Aur Banai, Kabupaten Sijunjung.
\end{abstract}

Keywords:aging, depression in old age, family support

Affiliasi penulis : Fakultas Kedokteran Universitas Andalas, Korespondensi :Figa Prima Dani, Email : figa15@yahoo.com, Telp: 0751-31746

\section{PENDAHULUAN}

Penduduk usia tua di Indonesia meningkat dari tahun ke tahun, ini disebabkan karena meningkatnya usia harapan hidup. Pada tahun 1980 usia harapan hidup di Indonesia 52,2 tahun dan jumlah usia tua $7.998,543$ orang $(5,45 \%)$, pada tahun 2006 menjadi 19 juta orang $(8,90 \%)$ danusia harapan hidupnya juga meningkat 66,2 tahun. Padatahun 2010 perkiraan penduduk usia tua di Indonesia akan mencapai 23,9 jutaatau $9,77 \%$ dan usia harapan hidup sekitar 67,4 tahun. Sepuluh tahun kemudian atau pada 2020 perkiraan penduduk usia tua di Indonesia mencapai 28,8 juta atau $11,34 \%$ dengan usia harapan hidup sekitar 71,1 tahun.

Secara umum kemunduran fisiologis yang terjadi pada usia tua baik secara fisik dan mental menyebabkan usia tua kurang peka terhadap berbagai rangsangan internal dan eksternal sehingga seorang usia tua rentan mengalami gangguan mental seperti depresi. Depresi merupakan satu masa terganggunya fungsi manusia yang berkaitan dengan alam perasaan yang sedih dan gejala penyertanya, termasuk perubahan pada pola tidur dan nafsu makan, psikomotor, konsentrasi, anhedonia, kelelahan, rasa putusasadantidakberdaya, sertabunuh diri. ${ }^{2-5}$

Depresi bisa menjadi masalah yang kronik dan berulang yang akan menyebabkan seseorang tidak mampu untuk mengurus diri sendiri, selain itu depresi dapat menjurus kepada tindakan bunuh diri. Depresi pada usia tua dapat dicegah dengan adanya dukungan keluarga. Dukungan keluarga merupakan gabungan sikap dan penerimaan yang dapat membantu usia tua menghadapi masalah. Ada beberapa bentuk dari dukungan keluarga yaitu dukungan informasi, dukungan penilaian, dukungan instrumental, dan dukungan emosional. ${ }^{2,4-6}$

Penelitian ini dilakukan di Nagari Tanjung Banai Aur, Kecamatan Sumpur Kudus, Kabupaten Sijunjung, karena kasus depresi di daerah ini menunjukkan keadaan yang menetap pada tahun 2010 dan tahun 2011. Penelitian ini bertujuan untuk mengetahui hubungan dukungan keluarga dengan kejadian depresi pada usia tua. 


\section{METODE}

Penelitian tentang dukungan keluarga dengan kejadian depresi pada usia tua dilakukan di nagari Tanjung Bana iAur, Kecamatan Sumpur Kudus, Kabupaten Sijunjung. Subjek dalam penelitian ini sebanyak 82 orang yang tersebar di empat nagari, dan metode pengambilan sampel stratified sampling. Instrument penelitian adalah kuesioner dengan wawancara dengan menggunakan geriatric depression scale untuk menilai tingkat depresi pada usia tuanya dan untuk menilai dukungan keluarga digunakan skala likert. Data yang diperoleh akan diolah dengan software computer yaitu SPSS, dan untuk analisis hasil penelitiannya digunakan Uji Chi Square dengan tingkat pemaknaan $\mathrm{p}<0,05$. $^{7-11}$

\section{HASIL}

a. Dukungan keluarga

Tabel1. Hubungan Dukungan Keluarga dengan Tingkat Depresi

\begin{tabular}{lllll}
\multirow{2}{*}{ DukunganKelurga } & \multicolumn{2}{c}{ Tingkat Depresi } & \multirow{2}{*}{ Total } & \multirow{2}{*}{ P Value } \\
\cline { 2 - 3 } & Normal & Depresi & & \\
\hline Tinggi & 13 & 17 & 30 & \multirow{2}{*}{0,005} \\
Rendah & 8 & 44 & 52 & \\
\hline Total & 21 & 61 & 82 & \\
\hline
\end{tabular}

Berdasarkan tabel diatas menunjukkan bahwa persentase depresi lebih tinggi pada dukungan keluarga rendah (84,6\%) dibandingkan dengan dukungan keluarga tinggi (56,7\%), dengan uji statistik didapatkan $\mathrm{p}=0,005$ terdapat hubungan yang signifikan $p<0,05$.

b. Dukungan informasi

Tabel 2. Hubungan Dukungan Informasi dengan Tingkat Depresi

\begin{tabular}{lllll}
\hline DukunganInformasi & \multicolumn{2}{c}{ Tingkat Depresi } & \multirow{2}{*}{ Total } & $\begin{array}{c}\text { P } \\
\text { Value }\end{array}$ \\
\cline { 2 - 4 } & Normal & Depresi & & \\
\hline Tinggi & 16 & 19 & 35 & \\
Rendah & 5 & 42 & 47 & 0,000 \\
\hline Total & 21 & 61 & 82 & \\
\hline
\end{tabular}

Berdasarkan tabel diatas menunjukkan bahwa persentase depresi lebih tinggi pada dukungan informasi rendah $(89,4 \%)$ dibandingkan dengan dukungan informasi tinggi $(54,3 \%)$, dengan uji statistic didapatkan $\mathrm{p}=0,000$ terdapat hubungan yang signifikan $p<0,05$.

\section{c. Dukungan penilaian}

Tabel 3. Hubungan Dukungan penilaian dengadengan depresi

\begin{tabular}{|c|c|c|c|c|}
\hline \multirow{2}{*}{ DukunganPenilaian } & \multicolumn{2}{|c|}{ Tingkat Depresi } & \multirow{2}{*}{ Total } & \multirow{2}{*}{$\begin{array}{c}\mathbf{P} \\
\text { Value }\end{array}$} \\
\hline & Normal & Depresi & & \\
\hline Tinggi & 11 & 17 & 28 & \\
\hline Rendah & 10 & 44 & 54 & 0,041 \\
\hline Total & 21 & 61 & 82 & \\
\hline
\end{tabular}

Berdasarkan tabel diatas $(81,5 \%)$ dibandingkan dengan dukungan penilaian tinggi $(60,7 \%)$, dengan uji statistic didapatkan $p=0,041$ terdapat hubungan yang signifikan $p<0,05$.

d. Dukungan instrumental

Tabel 4. Hubungan Dukungan Instrumental dengan Tingkat Depresi

\begin{tabular}{lllll}
\hline Dukungan & \multicolumn{2}{c}{ Tingkat Depresi } & Total & $\begin{array}{c}\text { P } \\
\text { Instrumental }\end{array}$ \\
\cline { 2 - 3 } & Normal & Depresi & & \\
\hline Tinggi & 16 & 15 & 31 & \\
Rendah & 5 & 46 & 51 & 0,000 \\
\hline Total & 21 & 61 & 82 & \\
\hline
\end{tabular}

Berdasarkan tabel diatas menunjukkan bahwa persentase depresi lebih tinggi pada dukungan instrumental rendah $(90,2 \%)$ dibandingkan instrumental tinggi $(48,4 \%)$, dengan uji statistic didapatkan $p=0,000$ terdapat hubungan yang signifikan $p<0,05$.

e. Dukungan emosional

Tabel 5. Hubungan Dukungan Emosional dengan Tingkat Depresi di nagari Tanjung Banai Aur, Kecamatan Sumpur Kudus, Kabupaten Sijunjung

\begin{tabular}{|c|c|c|c|c|}
\hline \multirow{2}{*}{ DukunganEmosional } & \multicolumn{2}{|c|}{ Tingkat Depresi } & \multirow{2}{*}{ Total } & \multirow{2}{*}{$\begin{array}{l}\mathbf{P} \\
\text { Value }\end{array}$} \\
\hline & Normal & Depresi & & \\
\hline Tinggi & 11 & 13 & 24 & \\
\hline Rendah & 10 & 48 & 58 & 0,007 \\
\hline Total & 21 & 61 & 82 & \\
\hline
\end{tabular}

Berdasarkan tabel diatas menunjukkan bahwa persentase depresi lebih tinggi pada dukungan emosional rendah $(82,8 \%)$ dibandingkan dengan dukungan emosional tinggi (54,2\%), dengan uji statistik didapatkan $p=0,007$ terdapat hubungan yang signifikan $p<0,05$.

\section{Pembahasan}

a. Hubungan Dukungan Keluarga dengan Tingkat Depresi

Dukungan keluarga merupakan suatu upaya pencegahan terjadinya depresi pada usia tua dimana dukungan keluarga merupakan suatu bentuk hubungan interpersonal yang melindungi seseorang dari efek stress, dukungan keluarga juga dapat memberi petunjuk tentang kesehatan mental, fisik, dan emosi usia tua. Dukungan keluarga tersebut dapat berupa dukungan informasi, dukungan penilaian, dukungan instrumental, dan dukungan emosional. ${ }^{4-6}$

Usia tua yang mendapat dukungan dari keluarganya akan memperlihatkan kondisi kesehatan fisik dan mental yang lebih baik dibanding usia tua yang sedikit mendapat dukungan keluarga, hal ini sesuai juga dengan penelitian yang dilakukan oleh peneliti. Dukungan keluarga juga merupakan bentuk terapi keluarga yang termasuk pada penatalaksanaan depresi pada usia tua sehingga usia tua dapat menjalankan hidupnya lebih baik dan terhindar dari depresi. $^{4-6}$

b. Hubungan Dukungan Informasi dengan Tingkat Depresi

Aspek dalam dukungan informasi adalah saran, sugesti, informasi yang dapat digunakan untuk 
menyeleseikan suatu masalah. Bentuk dukungannya dapat berupa pemberian nasehat, dorongan semangat, dan pemberian informasi mengenai lingkungan luar sehingga membuat sugesti yang baik pada diri usia tua tersebut. ${ }^{6}$

Berdasarkan penelitian ini, kurangnya dukungan informasi yang diterima oleh usia tua disebabkan karena usia tua jarang menceritakan masalah yang dihadapinya kepada anggota keluarga lainnya, sehingga mereka tidak mendapat nasehat dalam memecahkan masalahnya.

Usia tua juga tidak mendapat informasi mengenai kesehatan dari anggota keluarganya disebabkan karena keterbatasan pengetahuan anggota keluarga lain mengenai kesehatan, dan biasanya mereka hanya mendapat informasi mengenai kesehatan dari bidan dan kader setempat pada saat posyandu dilakukan. Jadi dengan kurangnya informasi mengenai kesehatan baik fisik ataupun mental dan kurangnya bantuan berupa saran untuk memecahan masalah, maka keadaan fisik usia tua akan tambah berat karena disertai dengan gangguan mental.

c. Hubungan Dukungan Penilaian dengan Tingkat Depresi

Dukungan penilaian berupa penghargaan positif terhadap usia tua, dorongan untuk maju, dan bimbingan umpan balik, sehingga usia tua dapat melihat sisi positif yang ada dalam. ${ }^{6}$

Berdasarkan penelitian ini, kurangnya dukungan penilaian yang diterima responden disebabkan karena kurang kepedulian anggota keluarga lain terhadap apa yang dilakukan oleh responden, sehingga usia tua tidak merasa dihargai atas tindakannya dan usia tua akan mudah mengalami gangguan mental seperti depresi.

d. Hubungan Dukungan Instrumental dengan Tingkat Depresi

Dukungan instrumental berupa dukungan langsung sesuai yang dibutuhkan usia tua. ${ }^{6}$

Berdasarkan penelitian ini, kurangnya dukungan instrumental yang diterima usia tua disebabkan karena kebanyakan pekerjaan responden adalah berladang karet sehingga saat usia nya lebih dari 60 tahun, mereka tidak kuat lagi untuk bekerja, oleh karena itu sebagian besar kehidupan mereka dibiayai oleh anggota keluarga lain, terutama dari anak-anaknya, namun anaknya tersebut juga memiliki keterbatasan keuangan sehingga tidak mampu memenuhi kebutuhan usia tua sepenuhnya.

Hal ini akan menjadi pemikiran bagi usia tua tersebut karena mereka akan merasa menjadi beban keluarga sehingga akan menyebabkan terjadinya depresi, dan salah satu yang dapat menyebabkan depresi pada usia tua adalah perubahan sosial. ${ }^{2}$

e. Hubungan Dukungan Emosional dengan Tingkat Depresi

Dukungan emosional mencakup ungkapan empati, kepedulian, dan perhatian terhadap individu sehingga individu tersebut merasa nyaman, dicintai, dan diperhatikan. ${ }^{6}$

Berdasarkan penelitian ini, kurangnya dukungan emosional yang diterima usia tua disebabkan karena usia tua banyak yang kehilangan pasangan hidupnya sehingga saat menghadapi masalah, usia tua tidak mempunyai tempat untuk berkeluh kesah, sedangkan anggota keluarga lain seperti anak dan cucunya terlalu sibuk dengan urusan masing-masing, sehingga usia tua tersebut kurang mendapat perhatian, empati, dan kepedulian dari keluarganya, karena salah satu faktor yang menyebabkan depresi pada usia tua adalah adanya perubahan psikologis berupa kehilangan orang yang dicintainya.

\section{KESIMPULAN}

Berdasarkanpenelitian yang telah dilakukan, dapat ditarik kesimpulan bahwa:

a. Terdapat hubungan yang signifikan antara dukungan informasi dengan tingkat depresi pada usia tua di nagari Tanjung Banai Aur, Kecamatan Sumpur Kudus, Kabupaten Sijunjung.

b. Terdapat hubungan yang signifikan antara dukungan penilaian dengan tingkat depresi pada usia tua di nagari Tanjung Banai Aur, Kecamatan Sumpur Kudus, Kabupaten Sijunjung.

c. Terdapat hubungan yang signifikan antara dukungan instrumental dengan tingkat depresi pada usia tua di nagari Tanjung Banai Aur, Kecamatan Sumpur Kudus, Kabupaten Sijunjung.

d. Terdapat hubungan yang signifikan antara dukungan emosional dengan tingkat depresi pada usia tua di nagari Tanjung Banai Aur, Kecamatan Sumpur Kudus, Kabupaten Sijunjung.

e. Terdapat hubungan yang signifikan antara dukungan keluarga dengan tingkat depresi pada usia tua di nagari Tanjung Banai Aur, Kecamatan Sumpur Kudus, Kabupaten Sijunjung.

\section{DAFTAR PUSTAKA}

1. Menkokesra. Tersedia dari: URL: HYPERLINK http://www.depsos.go.id/modules.php?name= News\&file=article\&sid=208,depsos tahun 2009).

2. Soejono $\mathrm{CH}$, Probosuseno, Kemala SN. Depresi pada pasien lanjut usia. Dalam: Buku Ajar IImu Penyakit Dalam Jilid III. Edisi ke-4. Jakarta: Pusat Penerbitan Departemen IImu Penyakit Dalam Fakultas Kedokteran Universitas Indonesia; 2006. hlm.1369-72.

3. Maslim R. Diagnosis gangguan jiwa,rujukan ringkas PPDGJ-III. Jakarta: Bagian IImu kedokteran Jiwa FK Unika Atma Jaya; 2001. hlm.64-5.

4. Wiguna IM. Sinopsis psikiatri jilid 1. Tangerang: Binarupa Aksara;2010.hlm.791803.

5. Wiguna IM. Sinopsis psikiatri jilid 2 . Tangerang: Binarupa Aksara;2010.hlm.903-7.

6. Tiar Estu. Buku ajar keperawatan Keluarga: riset, teori, dan praktik. Jakarta: penerbit Buku Kedokteran EGC; 2010.

7. Dermatology Nursing. The geriatric depression scale. 2003. Tersedia dari: URL: http://www.medscape.com.

8. Komputer Wahana. Mengolah Data Statistik Penelitian dengan SPSS 18.Jakarta: PT Elex Media Komputindo; 2011.

9. Muttaqin H. Rujukan cepat psikiatri. Jakarta: Penerbit Buku Kedokteran EGC; 2009. 
10. Notoatmodjo S. Metodologi penelitian kesehatan. Jakarta: Rineka Cipta; 2010.

11. Sastroasmoro S, Ismael S. Dasar-dasar metodologi penelitian klinis. Edisi ke-2. Jakarta: Perpustakaan Nasional RI Katalog Dalam Terbitan; 2002. 